\title{
ASSESSING THE QUALITY OF HIGHER EDUCATION SERVICES USING A MODIFIED SERVQUAL SCALE
}

\author{
Shpëtim Çerri ${ }^{1}$
}

\begin{abstract}
The purpose of the study is to assess the service quality in high public education in Albania, using the SERVQUAL approach. Today Albanian public universities are facing fierce competition from private universities, so they find imperative focusing firmly on service quality they offer to students. The paper reports on a modified SERVQUAL survey of students from five public universities in Albania. The survey aims to capture the perceptions and expectations students have about the service they receive in respective universities, leading to an evaluation of overall perceived service quality based on gap analysis.

The data analysis reveals interesting findings on students' perceptions of service quality in high education. The universities' management would benefit from these findings by knowing which gap should receive the most attention in order to gain competitive advantage. An improved service quality will also help them to face the competition from other high education institutions. The study confirms the SERVQUAL scale as a suitable tool in assessing service quality in public sector, holding the same strengths as in private sector. The continuous measurement of service quality in universities will help in engaging in a continuous improvement of this quality, creating a good basis for achieving higher objectives. Service quality measurement will also help in creating a marketorientation for public universities, focusing more on the student as a customer.
\end{abstract}

Keywords : SERVQUAL, higher education, service quality, Albania,

JEL Codes: M31

\section{Introduction}

The purpose of the study is to investigate the service quality dimensions in higher education, test the service quality models proposed by relevant literature, and to offer a basis for continuous measurement and management of service quality in higher education. Focusing on service quality and its measurement will help in creating customer-oriented standards for service quality, enabling universities embrace a market approach fin their activity.

During the last decades service quality has gained tremendous attention from managers and academics due to its considerable influence on business performance, cost reduction, customer satisfaction, customer loyalty and profitability (Chang and Chen, 1998; Cronin and Taylor, 1992; Gammie, 1992; Gummesson, 1998; Guru, 2003; Hallowell, 1996; Lasser et al., 2000; Leonard and Sasser, 1982; Newman, 2001; Silvestro and Cross, 2000; Sureshchander et al., 2002). Often and more the quality is considered as an investment for company, where the efforts for its improvement result in an increased clientele, increased levels of purchase from existing customers, and a rise in the company's profits (Parasuraman et al., 1985; Reichheld and Sasser, 1990; Rust et al. 1995). In many service industries purchasing power in the marketplace has shifted dramatically from a seller's market to a buyer's market. The nature of services in higher education is quite complex due to the length of the process and variety of variables affecting it. The level of quality of such a

\footnotetext{
${ }^{1}$ University “A. Xhuvani” Faculty of Economics Elbasan, Albania, e-mail: cerri_shpetim@yahoo.com
} 
service is important since it contributes to the perceptions of the quality of the total educational experience. To gain a competitive advantage among other higher education institutions, universities require greater focus on service quality. Therefore, the universities seek to examine their strategic positions by evaluating existing services, and adapting to customers' perceptions to enhance their leadership position. Another imperative factor is the rapid growth of private universities in Albania, already outnumbering the public ones. This has created a huge competitive pressure on public universities, since private universities hold a more market approach and are more flexible towards the dynamic environment. They are already steps forward from public universities, considering their abilities and possibilities in implementing effective marketing policies toward their actual and prospective students. Defining and measuring service quality in universities will serve as an initial step towards a more student-friendly education service and in improving overall service. It will help in establishing clear customer-oriented standards and creating benchmarks for comparing service quality in public and private universities.

\section{Literature review}

There exists a vast literature on service quality, as well as many definitions on its conceptualization and dimensions. According to Juran (1988), "Quality is fitness for use, the extent to which the product successfully serves the purpose of the user during usage. Crosby (1982) stated "Quality is conformance to requirements. Gronroos (1984) was one of the first academics who dealt exclusively with service quality. According to him, service quality is comprised of two dimensions: technical quality and functional quality. Technical quality concerns the outcome, or what the customer received from the service and can be measured similarly to the assessment of product quality. Functional quality concerns the process of evaluating the manner of delivering the service. Image is an important influencing factor of service quality, serving as a filter in perception of service quality as favorable, neutral or unfavorable (Gronroos 1984, 2000). The perceived service quality stems from the comparison of expected quality, or the quality anticipated before the service consumption, with the perceived service quality obtained during the service consumption. If service expectations are confirmed during consumption, i.e. the service performance is up to what was anticipated, the quality of service is considered positive. Contrary, if the service performance is lower than the consumer expectations, the service quality is said to be negative.

U. Lehtinen and J. R. Lehtinen (1982) conceptualized service quality as comprised of three dimensions: physical quality; interactive quality, and corporate quality. Physical quality dimensions refers to the quality of physical elements of service, including tangible products elements that accompany the service offer, supporting equipment and the physical environment where service takes place. Interactive quality dimension refers to the quality of interaction between customer and other elements of service experience, i.e. service personnel, other customers, and machinery and equipment. Corporate quality is the quality dimension which is developed through the years of existence of a service company. It has a symbolic nature and refers to the way potential customers view the corporate entity, its image or profile.

In 1985 Parasuraman, Zeithaml and Berry published the results of a thorough study they conducted on service quality. They identified ten dimensions of service quality, which were presented together with a model of service quality. They were accessibility, reliability, responsiveness, competence, courtesy, communication, credibility, security, understanding the customer, and tangibles (for example physical facilities). Based on disconfirmation models, Parasuraman et al. supported the idea that service quality results from a comparison of customer perceptions about the service and the actual performance of service. In a refined study in 1988, Parasuraman et al. reduced the original number of service quality dimensions from ten to five, contending that these five dimensions fully capture the domain of service quality. The five final service quality components, according to them, are:

1. Tangibles: physical facilities, equipment and appearance of personnel; 
2. Reliability: ability to perform the promised service dependability and accurately;

3. Responsiveness: willingness to help customers and provide prompt service;

4. Assurance: knowledge and courtesy of employees and their ability to inspire trust and confidence;

5. Empathy: caring, individualized attention that a firm provides to its customers.

Parasuraman et al (1988) also developed an instrument for assessing service quality, named SERVQUAL, which is a multiple-item scale with good reliability and validity. There are two parts that assess service quality: (1) an expectations section containing 22 statements to measure customers' expectations of service quality, and (2) a perceptions section containing a matching set of 22 statements to measure how customers perceive service quality. The items in the two parts (expectations and perceptions) use the same phrases except that one asks about what the respondent expects from an excellent service provider and the other asks about actual (perceived) service. Consumers give their evaluations on expectations and perceptions of service quality on a seven point Likert scale, ranging from "completely disagree" to "completely agree". Service quality is calculated using differences (gaps) between expectations and perceptions evaluations. Parasuraman et al. (1991) reported that SERVQUAL scale is a very useful starting point for measuring service quality and that SERVQUAL can be supplemented with additional findings regarding gap scores. They support their scale, arguing that SERVQUAL can be used in various industries, modified when necessary according to industry characteristics. Wisniewski (2001) suggests that SERVQUAL can be applied across a broad range of service organizations coming from different sectors, since it employs psychometric testing and trials. Indeed, since its introduction, SERVQUAL scale has been tested and used in various contents. Examples are numerous:

- auto repair (Bouman and Van der Wiele, 1992);

- banking (Angur et al., 1999; Avkiran, 1999, Lassar et al., 2000; Newman, 2001;);

- education (Kwan and Ng, 1999; Oldfield and Baron, 2000; Shekarchizadeh et al., 2011).

- healthcare (Andaleeb, 1998; Babakus and Mangold, 1992; Wong, 2002)

- professional services (Hoxley, 2000; Philip and Hazlett, 2001);

- public services (Carman, 1990; Brysland and Curry, 2001; Donelly et al., 2006; Wisniewski, 2001);

- retailing (Finn and Lamb, 1991; Mehta et al., 2000);

- telecommunication (Lai et al., 2007; Van der Wal et al., 2002);

- transportation and shipping (Frost and Kumar, 2001; Sultan and Merlin, 2000);

SERVQUAL scale was the basis for developing the scale used in this study for measuring service quality in Albanian universities. The statements regarding expectations and perceptions on service quality were modified, aiming to better fit the scale to higher education service characteristics. The resulting scale contains 22 pairs of statements regarding expectations and perceptions of students on service quality offered by the faculty they're studying.

\section{Service quality in higher education}

Several studies have focused on service quality in higher education. Stewart and Felicetti (1991) reported that a majority of students' in their study were dissatisfied with their business school for what they perceived to be insufficient orientation assistance on their arrival at the school. Tomovick, Jones and AI-Khatib (1996) examined the factors that influence the service quality perceptions of international students in US business schools. They adapted the SERVQUAL for an educational setting. It contained 20 of the original 22 SERVQUAL items. They dropped, after pretesting, two items deemed inappropriate for the educational setting. They assessed both discriminant and convergent validity of the modified scale, keeping the five dimensions of the SERVQUAL (tangibles, reliability, responsiveness, assurance, and empathy). They found that international business students considered tangibles (e.g. of appealing facilities) one of the two most important factors in their assessment of educational service quality. The other construct found to 
influence students' service perception was assurance. This finding suggested that a school's faculty and their ability to interact comfortably with foreign students can positively affect students' perception. Students not only expect knowledgeable and qualified faculty but also frequently need teachers or mentors who will help them with the sometimes-troublesome transition to a new school, a new country, and a new culture.

Remenyi and Money (1994) conducted a study into the computer services offered at Henley Management College in the UK. They examined service quality gap and correspondence analysis as diagnostic tools. Questionnaires were distributed to users of the information system in an attempt to measure user satisfaction with the computer network, the information systems staff, and the other information system services offered by the business school. The result showed that there is indeed a problem with service provided by the business school's information systems department which suggested the ineffective employment if information resources.

Rigotti and Pitt (1992) modified the SERVQUAL instrument for full-time and part-time MBA students in a three weeks executive development program at a business school. Questionnaires regarding management's perceptions of customer expectations were also issued to academic staff and senior administration personnel. They reported acceptable reliability and validity of the instrument for use with education services.

McElwee and Redman (1993) developed QUALED scale to assess service quality in higher education. They proposed that there are three characteristics endemic to the service sector: intangibility, heterogeneity and inseparability. Intangibility applies to higher education because most but not all of the services are courses. It is not possible to measure them precisely. They cannot be evaluated as outcomes other than in terms of course classifications or grades. Heterogeneity refers to the diversity of services offered. For higher education institutions, the services can include postgraduate courses; vocational courses; graduate courses; miscellaneous others such research, consultancy and other support activities. According to Parasuraman,et al. (1985): "consistency of behaviour from service personnel (i.e. uniform quality) is difficult to assure because what to deliver may be entirely different from what the consumer receives" (p.42). Inseparability, according to Parasuraman et al. (1985) described the situation when production of a service is inseparable from consumption of the service. In higher education terms it is probably widely accepted that, as yet, there is less managerial control over the actual content of course and modules. The assumption is that the people who deliver the courses have some degree of expertise and academic knowledge. Thus the monitoring of the student/lecturer teaching/learning interface is minimal.

Based on an extensive literature review regarding service quality and service quality in higher education, five hypotheses were formed:

H1: Tangibles is a significant driver of customer's perception of service quality in higher education;

H2: Reliability is a significant driver of customer's perception of service quality in higher education;

H3: Responsiveness is a significant driver of customer's perception of service quality in higher education;

H4: Assurance is a significant driver of customer's perception of service quality in higher education;

H5: Empathy is a significant driver of customer's perception of service quality in higher education. 


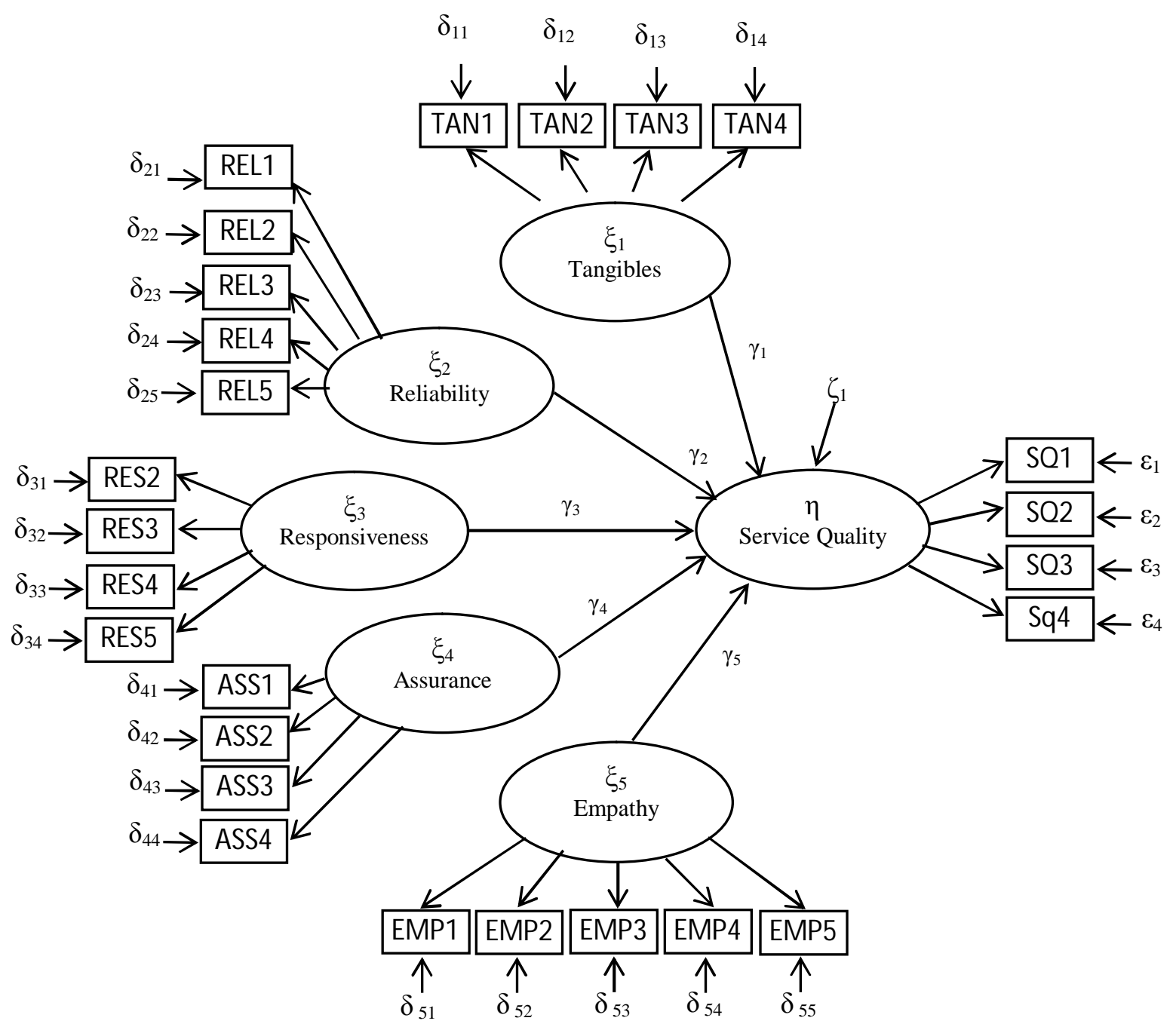

Figure no. 1 - The Hypothesized of Model of Determinants of Service Quality

Table no. 1.

\section{Constructs and Variables in the Structural Equation Model} (adapted from Çerri, 2012 and Hair, 2009)

\begin{tabular}{|l|l|}
\hline Type & Description of constructs or variables \\
\hline Latent constructs & $\begin{array}{l}\text { The } \xi \text { 's }(\text { Greek } k \text { si) are latent exogenous variables: Tangibles; Reliability; } \\
\text { Responsiveness; Assurance and Empathy. } \\
\text { The } \eta \text { 's }(\text { Greek } \text { eta }) \text { are latent endogenous variables: Service Quality in } \\
\text { the presented model }\end{array}$ \\
\hline Manifest variables & $\begin{array}{l}\text { They are actual measures or scores of latent constructs and are put in } \\
\text { square boxes: } \\
\text { - e.g. TAN1, TAN2, TAN3 and TAN4 are indicators of Tangibles } \\
\text { variable. } \\
\text { - SQ1, SQ2 and SQ3 and SQ4 are indicators of Service Quality variable). }\end{array}$ \\
\hline
\end{tabular}




\begin{tabular}{|c|c|}
\hline $\begin{array}{l}\text { Coefficient } \\
\text { parameters }\end{array}$ & $\begin{array}{l}\text { The } \gamma \text { 's (Greek gamma) are structural parameters (regression coefficients } \\
\text { or path coefficients) relating the endogenous constructs to the exogenous } \\
\text { constructs. }\end{array}$ \\
\hline Error parameters & $\begin{array}{l}\text { The } \delta \text { 's (Greek delta) are measurement errors for indicators of exogenous } \\
\text { variables. } \\
\text { The } \varepsilon \text { 's (Greek epsilon) are measurement errors for indicators of } \\
\text { endogenous variables. } \\
\text { The } \zeta \text { 's (Greek zeta) are random disturbance terms. They playa role } \\
\text { analogous to the error in a single-equation regression model }\end{array}$ \\
\hline
\end{tabular}

Then, after testing the five hypotheses and confirming the five dimensions service quality model proposed by Parasuraman et al. (1991), the formal measurement of service quality was performed. The SERVQUAL scale was modified in item wordings and some of the statements were re-formulated, in order to better capture the service quality dimensions in a higher education setting. The modified scale kept the focus on five original dimensions of service quality proposed by Parasuraman et al. (1991), namely tangibles, reliability, responsiveness, assurance, and empathy.

\section{Research methodology}

Five public universities were chosen as setting for conducting the study regarding service quality in higher education. They all offer programs in bachelor and master level. Two of them offer also doctoral studies ( $\mathrm{PhD})$. The sample of the study consists of 261 students from bachelor and master programs. The collection of the data lasted for two weeks, and ten interviewers were engaged in this process. They were preliminary trained and introduced to the interviewing process and SERVQUAL questionnaire. The profiles of the respondents are presented in Table 2.

Table no. 2 .

Sample's characteristics

\begin{tabular}{|l|c|c|}
\hline & Frequency & Percentage \\
\hline Study Program & & \\
\hline Bachelor level & 185 & 70.88 \\
\hline Master level & 76 & 29.12 \\
\hline TOTAL & $\mathbf{2 6 1}$ & $\mathbf{1 0 0 . 0 0}$ \\
\hline Gender & & 47.51 \\
\hline Male & 124 & 52.49 \\
\hline Female & 137 & $\mathbf{1 0 0 . 0 0}$ \\
\hline TOTAL & $\mathbf{2 6 1}$ & \\
\hline Higher Education & & 26.05 \\
Institution & & 19.92 \\
\hline University 1 & 68 & 14.18 \\
\hline University 2 & 52 & 25.29 \\
\hline University 3 & 37 & 14.56 \\
\hline University 4 & 66 & $\mathbf{1 0 0 . 0 0}$ \\
\hline University 5 & 38 & $\mathbf{2 6 1}$ \\
\hline TOTAL & & \\
\hline
\end{tabular}


The hypotheses were tested using structural equation modeling (SEM) approach. Structural Equations Modeling (SEM) is a comprehensive statistical approach for testing hypotheses about relations between observed and latent variables (Hair et al., 2009). It combines features of factor analysis and multiple regressions for studying both the measurement and the structural properties of theoretical models (Çerri, 2012). The proper selection of Structural Equation Modeling is a crucial part of the research study (Davis, 1996; Stevens, 2002). According to Stevens, (2002) SEM allows for the testing of models with varying degrees of dependent variables, while measuring model error to bridge the gap between the latent variable.

SEM is formally defined by two sets of linear equations called the inner model and the outer model. The inner model specifies the relationships between unobserved or latent variables, and the outer model specifies the relationships between latent variables and their associated observed or manifest variables (Gefen et al., 2000).

The constructs of the model are unobservable (latent) variables indirectly described by a block of observable variables, which are called manifest variables or indicators. The constructs and their observable items are given in Table 3.

Table no. 3 .

\section{Latent and manifest variables}

\begin{tabular}{|l|l|}
\hline Latent Variables & Manifest variables \\
\hline Tangibles $\left(\xi_{1}\right)$ & TAN1: The faculty has modern and latest equipment. \\
\hline & $\begin{array}{l}\text { TAN2: The appearance of the physical facilities of the faculty is } \\
\text { attractive. }\end{array}$ \\
\hline & TAN3: Staff is well dressed and neat in appearance \\
\hline & TAN4: Library has the latest literature in your area of interest. \\
\hline Reliability $\left(\xi_{2}\right)$ & $\begin{array}{l}\text { REL1: When something is promised by a certain time, it always is } \\
\text { provided by staff. }\end{array}$ \\
\hline & $\begin{array}{l}\text { REL2: When students have problems, staff is courteous, even if not } \\
\text { able to help. }\end{array}$ \\
\hline & REL3: Courses are taught by highly knowledgeable professors. \\
\hline & REL4: The teaching staff respects lectures and exams schedules. \\
\hline & REL5: Faculty staff keeps accurate records. \\
\hline Responsiveness $\left(\xi_{3}\right)$ & $\begin{array}{l}\text { RES1: Students are informed of schedules and changes in } \\
\text { schedules in advance. }\end{array}$ \\
\hline & RES2: Service hours of learning facilities accommodate all students \\
\hline & RES3: Faculty staff is always willing to help you. \\
\hline & $\begin{array}{l}\text { RES4: Administrative staff are never too busy respond to student } \\
\text { requests promptly }\end{array}$ \\
\hline & ASS1: The behavior of faculty staff instills confidence in you. \\
\hline & ASS2: Students are able to trust the faculty staff. \\
\hline ASS3: Faculty staff is friendly and polite \\
\hline Assurance $\left(\xi_{4}\right)$ & ASS4: Teaching staff is dependable. \\
\hline & EMP1: Faculty provide personal attention to every student \\
\hline & EMP2: Professors have convenient office-hours to advise students \\
\hline Empathy $\left(\xi_{5}\right)$ & EMP3: Staff members give students individual attention \\
\hline & EMP4: Faculty has students' best interest as a major objective \\
\hline &
\end{tabular}




\begin{tabular}{|l|l|}
\hline Service Quality $(\eta)$ & SQ1: Faculty provides excellent overall service \\
\hline & SQ2: Faculty provides superior service in every way \\
\hline & SQ3: The standards of service in this faculty are very high \\
\hline & SQ4: The quality of service in this faculty is very high \\
\hline
\end{tabular}

In order to identify the underlying constructs and indicators, as well as to test the construct reliability and validity, Cronbach's alpha, factor analysis and confirmatory factor analysis were used. Path analysis was employed in testing the hypotheses of the study, achieving estimated path coefficients, which are interpreted as standardized weights (beta $\beta$ ) in multiple regression equation.

\section{Data analysis and results}

The first step was conducting factor analysis, using (PAF) extraction method and oblimin rotation procedure. SPSS 17 software was used for this kind of analysis. PAF was preferred instead of Principal Component Analysis (PCA) because the first is better for obtaining parameters reflecting latent constructs or factors (Hair et al., 2009; Widaman, 1993). The purpose of the examination was the assessing of dimensionality of scales used in the study. The criterion of the eigenvalue above 1 for each construct was used in the factor analysis.

The computation of coefficient alpha was conducted separately for the six latent constructs, aiming to verify the extent to which items making up each construct shared a common score. All the items had satisfactory factor loadings (more than 0.5) (Comrey, 1973), low cross loadings (lower than 0.4) and neither of them reported item-to-total correlations (more than 0.3) (Janda et al., 2002). So, all of them were judged appropriate for further analysis. The factor structure resulted in compliance with the proposed instrument, confirming 26 items as representatives of 5 dimensions of service quality and service quality itself. The overall factor solution explains 73.481 per cent of the variation for the factor structure model, resulting in very good loading patterns.

The results of factor analysis are presented in Table 4 .

Table no. 4.

Factor analysis for service quality constructs

\begin{tabular}{|l|r|r|r|r|r|r|r|}
\hline Factor/ Item & Tangibles & Reliability & $\begin{array}{c}\text { Responsi } \\
\text { veness }\end{array}$ & Assurance & Empathy & $\begin{array}{c}\text { Service } \\
\text { Quality }\end{array}$ & $\begin{array}{c}\text { Cumulative } \\
\text { percentage of } \\
\text { variance } \\
\text { explained }\end{array}$ \\
\hline TAN1-S1 & 0.597 & & & & & & \\
TAN2-S2 & 0.689 & & & & & & \\
TAN3-S3 & 0.795 & & & & & \\
TAN4-S4 & 0.819 & & & & & & \\
\hline REL1-S5 & & 0.798 & & & & \\
REL2-S6 & & 0.834 & & & & \\
REL3-S7 & & 0.698 & & & & \\
REL4-S8 & & 0.781 & & & & \\
REL5-S9 & & 0.593 & & 0.874 & & & \\
\hline RES1-S10 & & & 0.692 & & & \\
RES2-S11 & & & 0.729 & & & \\
RES3-S12 & & & 0.795 & & 0.952 & & \\
RES4-S13 & & & & 0.971 & & & \\
\hline ASS1-S14 & & & & 0.794 & & & \\
ASS2-S15 & & & & & & \\
ASS3-S16 & & & & & & \\
ASS4-S17 & & & & & & \\
\hline
\end{tabular}




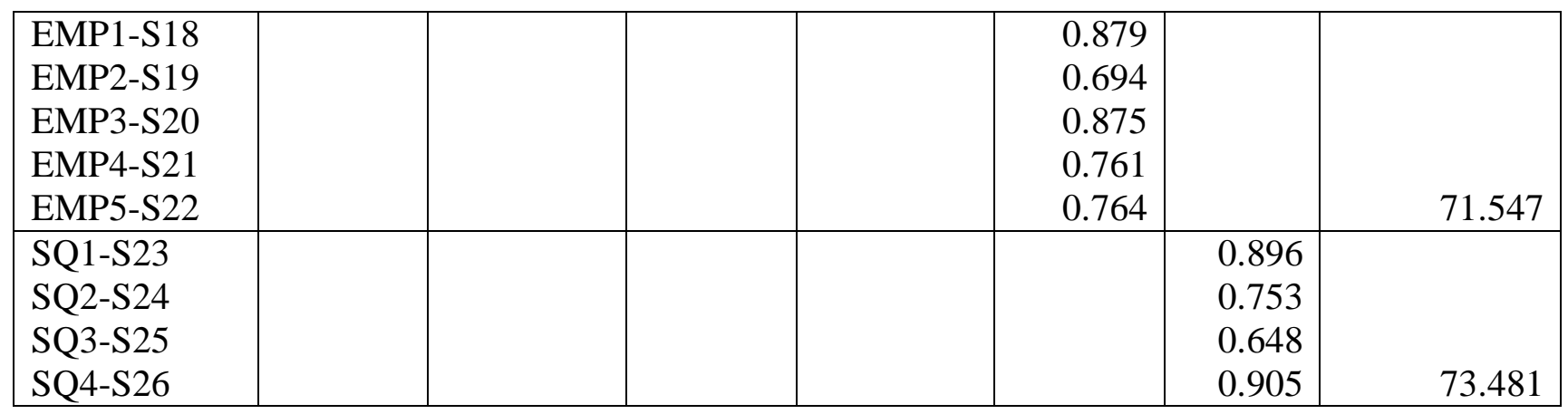

Then confirmatory factory analysis (CFA) was conducted in order to further asses the dimensionality, reliability and validity of the model. Table 5 presents the results of the CFA. The goodness-of-fit indicators suggest that the structure proposed is well established (GFI $=0.96$; AGFI $=0.95 ; \mathrm{CFI}=1.0 ; \mathrm{RMSEA}=0.01)$. All the standardized loadings are significant at a $p$ value of 0.01 .

Table no. 5 .

Standardized measurement coefficients resulting from Confirmatory Factor Analysis

\begin{tabular}{|l|r|}
\hline Construcs/Items & $\begin{array}{c}\text { Standard } \\
\text { loadings }\end{array}$ \\
\hline Tangibles & 0.73 \\
S1: The faculty has modern and latest equipment. & 0.91 \\
S2: The appearance of the physical facilities of the faculty is attractive. & 0.74 \\
S3: Staff is well dressed and neat in appearance & 0.69 \\
S4: Library has the latest literature in your area of interest. & \\
\hline Reliability & 0.78 \\
S5: When something is promised by a certain time, it always is provided by & \\
staff. & 0.74 \\
S6: When students have problems, staff is courteous, even if not able to help. & 0.90 \\
S7: Courses are taught by highly knowledgeable professors. & 0.88 \\
S8: The teaching staff respects lectures and exams schedules. & 0.76 \\
S9: Faculty staff keeps accurate records. & 0.64 \\
\hline Responsiveness & 0.69 \\
S10: Students are informed of schedules and changes in schedules in advance. & 0.73 \\
S11: Service hours of learning facilities accommodate all students & 0.85 \\
S12: Faculty staff is always willing to help you. & \\
S13: Administrative staff are never too busy respond to student requests & 0.77 \\
promptly & 0.81 \\
\hline Assurance & 0.89 \\
S14: The behavior of faculty staff instills confidence in you. & 0.71 \\
\hline S15: Students are able to trust the faculty staff. & 0.69 \\
S16: Faculty staff is friendly and polite & 0.62 \\
S17: Teaching staff is dependable. & 0.76 \\
\hline Empathy & 0.83 \\
S18: Faculty provide personal attention to every student & 0.66 \\
\hline S19: Professors have convenient office-hours to advise students & \\
S20: Staff members give students individual attention & \\
S21: Faculty has students' best interest as a major objective & \\
S22: Faculty understands the specific needs of students. & \\
\hline
\end{tabular}




\begin{tabular}{|l|r|}
\hline Service Quality & 0.88 \\
S23: Faculty provides excellent overall service & 0.79 \\
S24: Faculty provides superior service in every way & 0.91 \\
S25: The standards of service in this faculty are very high & 0.69 \\
S26: The quality of service in this faculty is very high & \\
\hline Goodness of Fit Indicators & \\
GFI $=0.96 ;$ AGFI $=0.95 ;$ CFI $=1.0 ;$ RMSEA $=0.01$ & \\
$p$-value $=0.01$ & \\
\hline
\end{tabular}

\section{Convergent validity}

Convergent validity is the extent to which different approaches to measurement of construct yield the same results. The most commonly used way to assess convergent validity is to consider each item in the scale as a different approach to measure the construct. Convergent validity is checked using the Bentler- Bonett coefficient $(\Delta)$ (Bentler and Bonett, 1980). The Bentler-Bonett coefficient $(\Delta)$ is the ratio of the difference between the chi-square value of the null measurement model and the chi-square value of the specified measurement model to the chi-square value of the null model. As shown in Table 6, the Bentler-Bonett coefficients $(\Delta)$ for all eight constructs are greater than 0.90 , meaning that strong convergent validity of scale was demonstrated.

Table no.6.

Unidimensionality, Reliability and Convergent Validity assessment indicators

\begin{tabular}{|l|c|c|c|c|}
\hline \multicolumn{1}{|c|}{ Construct } & $\begin{array}{c}\text { Number of } \\
\text { items }\end{array}$ & $\begin{array}{c}\text { Unidimensionality } \\
\text { Goodness of fit } \\
\text { index (GFI) }\end{array}$ & $\begin{array}{c}\text { Reliability } \\
\text { Cronbach's } \\
\boldsymbol{\alpha}\end{array}$ & $\begin{array}{c}\text { Convergent } \\
\text { validity } \\
\text { Bentler-Bonett } \\
\boldsymbol{\Delta}\end{array}$ \\
\hline Tangibles & 4 & 0.98 & 0.94 & 0.96 \\
\hline Reliability & 5 & 0.97 & 0.91 & 0.98 \\
\hline Responsiveness & 4 & 0.96 & 0.83 & 0.93 \\
\hline Assurance & 4 & 0.95 & 0.79 & 0.97 \\
\hline Empathy & 5 & 0.95 & 0.92 & 0.97 \\
\hline Service quality & 4 & 0.93 & 0.88 & 0.92 \\
\hline
\end{tabular}

\section{Discriminant validity}

Discriminant validity is the degree to which measures of different scales of the survey instrument are unique from each other. Discriminant validity exists when the proportion of variance extracted in each construct (Average Variance Extracted - AVE) exceeds the square of the coefficient representing its correlation with other constructs (Fornell and Larcker, 1981). As shown in Table 7, correlation coefficients are all significant at 0.01 level. In addition, all AVE exceed .50, indicating solid the construct validity.

Table no. 7.

Correlations, Squared correlations and Average Variance Extracted for the latent variables

\begin{tabular}{|l|l|l|l|l|l|l|l|}
\hline Construct & TAN & REL & RES & ASS & EMP & SQ & AVE \\
\hline TAN & 1.00 & & & & & & 0.88 \\
\hline REL & 0.77 & 1.00 & & & & & 0.92 \\
\hline RES & 0.54 & 0.68 & 1.00 & & & & 0.79 \\
\hline ASS & 0.39 & 0.47 & 0.65 & 1.00 & & & 0.84 \\
\hline EMP & 0.78 & 0.68 & 0.72 & 0.47 & 1.00 & & 0.81 \\
\hline SQ & 0.74 & 0.47 & 0.42 & 0.38 & 0.56 & 1.00 & 0.76 \\
\hline \multicolumn{7}{|l|}{ The p-value are all less than 0.01. } \\
\hline
\end{tabular}


The results of the confirmatory factor analysis provided support for the reliable measurement of the model.

\section{Hypotheses and paths testing}

The statistical significance of all the structural parameter estimates was examined to determine the validity of the hypothesized paths. Table 8 lists the structural parameter estimates and the hypothesis testing results.

Table no. 8 .

Structural parameter estimates for the hypothesized model

\begin{tabular}{|l|c|c|c|c|}
\hline Casual path & Hypothesis & $\begin{array}{c}\text { Standardized } \\
\text { path coefficient }\end{array}$ & t-value & $\begin{array}{c}\text { Assessment } \\
(\boldsymbol{p}<\mathbf{0 . 0 1})\end{array}$ \\
\hline TAN $\rightarrow$ SQ & Supported & 0.58 & 2.85 & Significant \\
\hline REL $\rightarrow$ SQ & Supported & 0.47 & 4.24 & Significant \\
\hline RES $\rightarrow$ SQ & Supported & 0.33 & 2.79 & Significant \\
\hline ASS $\rightarrow$ SQ & Supported & 0.37 & 4.14 & Significant \\
\hline EMP $\rightarrow$ SQ & Supported & 0.29 & 3.98 & Significant \\
\hline
\end{tabular}

All the five hypotheses were fully supported. This means that five dimensions of service quality, i.e. Tangibles, Reliability, Responsibility, Assurance, and Empathy positively and significantly affect Service Quality. These results confirm the findings of Parasuraman et al (1991) and other studies arguing the appropriateness of SERVQUAL model in higher education service quality.

The second purpose of the study was to measure the service quality using the modified SERVQUAL scale. The aim was to arrive in a numerical evaluation of service quality in higher education institutions chosen for the study. The respondents were asked to give their opinion about each statement concerning expectations and perceptions, in a 7-point Likert scale. The range of scale is from 1 (corresponding to "Strongly Disagree") to 7 (corresponding to "Strongly Disagree"). Table 9 lists the means scores on expectations and perceptions scales for each of the 22 service quality attributes, together with the mean gap score. In order to test the significant mean gap between student's expectations and perceptions of service quality, the paired t-test was employed.

Table no. 9.

Service quality scores for expectations, perceptions, and gap values.

\begin{tabular}{|l|l|l|l|l|}
\hline Statement & $\begin{array}{l}\text { Exp. mean } \\
\text { (Standard } \\
\text { Deviation) }\end{array}$ & $\begin{array}{l}\text { Per. mean } \\
\text { (Standard } \\
\text { Deviation) }\end{array}$ & Gap & t-value \\
\hline 1. $\quad$ Modern and latest equipment & $6.67(0.71)$ & $6.26(1.77)$ & -0.41 & $1.978^{*}$ \\
\hline $\begin{array}{l}\text { Attractiveness of the appearance of faculty's physical } \\
\text { facilities }\end{array}$ & $5.11(1.65)$ & $5.00(1.93)$ & -0.11 & $6.231^{*}$ \\
\hline 3. $\quad$ Neat appearance of staff & $6.41(1.83)$ & $5.85(1.23)$ & -0.56 & $5.487^{* *}$ \\
\hline 4. $\quad$ Latest literature of interest in library & $6.09(1.32)$ & $5.16(1.72)$ & -0.93 & $0.547^{*}$ \\
\hline 5. $\quad$ Staff provides everything promised by a certain time & $5.78(1.18)$ & $5.64(1.65)$ & -0.14 & $4.258^{*}$ \\
\hline $\begin{array}{l}\text { 6. } \\
\text { Staff to be ever willing to help when students have }\end{array}$ & $5.53(1.15)$ & $4.92(1.62)$ & -0.61 & $7.315^{*}$ \\
\hline 7. $\quad \begin{array}{l}\text { Courses to be taught by highly knowledgeable } \\
\text { professors. }\end{array}$ & $6.59(1.01)$ & $5.92(1.90)$ & -0.67 & $8.194^{*}$ \\
\hline 8. $\quad$ Teaching staff respecting lectures and exams schedules. & $5.85(2.42)$ & $3.79(1.81)$ & -2.06 & $6.658^{*}$ \\
\hline 9. Staff keeping accurate records & $6.41(1.27)$ & $5.86(1.62)$ & -0.55 & $5.895^{*}$ \\
\hline 10. $\begin{array}{l}\text { Informing students of schedules and changes in } \\
\text { schedules in advance }\end{array}$ & $5.77(1.54)$ & $5.70(1.13)$ & -0.07 & $9.254^{*}$ \\
\hline 11. Service hours of learning facilities accommodating all & $6.41(1.34)$ & $5.75(1.14)$ & -0.66 & $5.691^{*}$ \\
\hline
\end{tabular}




\begin{tabular}{|c|c|c|c|c|}
\hline Statement & $\begin{array}{l}\text { Exp. mean } \\
\text { (Standard } \\
\text { Deviation) }\end{array}$ & $\begin{array}{l}\text { Per. mean } \\
\text { (Standard } \\
\text { Deviation) }\end{array}$ & Gap & t-value \\
\hline students & & & & \\
\hline 12. Faculty staff willingness to help students & $5.75(1.47)$ & $5.74(1.66)$ & -0.01 & $7.658^{*}$ \\
\hline $\begin{array}{l}\text { 13. Administrative staff responding promptly to students' } \\
\text { requests }\end{array}$ & $6.43(1.34)$ & $5.80(1.34)$ & -0.63 & $5.369 *$ \\
\hline $\begin{array}{l}\text { 14. The behavior of faculty staff instilling confidence in } \\
\text { students }\end{array}$ & $6.41(1.90)$ & $5.87(1.20)$ & -0.54 & $6.873^{*}$ \\
\hline 15. Students being able to trust the faculty staff. & $6.48(1.41)$ & $5.62(1.27)$ & -0.86 & $6.631 *$ \\
\hline 16. Faculty staff being friendly and polite & $6.40(1.69)$ & $5.68(1.62)$ & -0.72 & $7.547 *$ \\
\hline 17. Teaching staff being dependable. & $6.06(1.71)$ & $5.58(1.38)$ & -0.48 & $5.587 *$ \\
\hline 18. Faculty providing personal attention to every student & $6.43(2.31)$ & $6.17(1.84)$ & -0.26 & $9.658 * *$ \\
\hline $\begin{array}{l}\text { 19. Professors having convenient office-hours to advise } \\
\text { students }\end{array}$ & $5.43(1.83)$ & $5.38(1.61)$ & -0.05 & $7.124 * *$ \\
\hline 20. Staff members giving students individual attention & $6.73(1.93)$ & $5.99(1.09)$ & -0.74 & $7.125^{*}$ \\
\hline 21. Faculty having students' best interest as a major objective & $4.42(1.74)$ & $3.85(1.67)$ & -0.57 & $5.036^{*}$ \\
\hline 22. Faculty understanding the specific needs of students. & $4.57(1.15)$ & $3.22(0.94)$ & -1.35 & $9.367^{*}$ \\
\hline
\end{tabular}

The 22 statements give the necessary input information about student's perceptions and expectations of faculty services. Of 22 attributes, only two of them had a mean expectation score lower than 5.00 ("Faculty having students' best interest as a major objective" and "Faculty understanding the specific needs of students"). The attributes with lower mean perceptions scores $(<4)$ were "Teaching staff respecting lectures and exams schedules", "Faculty having students' best interest as a major objective", and "Faculty understanding the specific needs of students". All the perceptions mean scores were lower than respective expectation score, indicating negative service quality for all the attributes and, consequently, for all the dimensions comprising service quality. The magnitude of gap varies from - 0.01 which corresponds to "Faculty staff willingness to help students", to -2.06 which corresponds to "Teaching staff respecting lectures and exams schedules".

The gap scores also allow for dimension-level analysis of service quality. By examining the mean gap scores for each dimension, reliability has the worst result, scoring -0.806 , followed by assurance (mean gap score -0.65), empathy (mean gap score 0.594), tangibles (mean gap score 0.502), and responsiveness (mean gap score -0.342).

\section{Discussion and conclusions}

The study has fulfilled the objectives presented at the beginning of this material. The five dimension service quality model proposed by Parasuraman et a. (1991) was successfully tested, and service quality measurement based on gap analysis was performed. The hypotheses that tangibles, reliability, responsiveness, assurance and empathy are significant drivers of service quality in higher education were positively confirmed. The findings of the study support previous studies on service quality conducted by various researchers, who conclude that these five dimensions are the antecedents of service quality. This study also adds to other published researches which contend that this model is applicable in a wide range of services sectors, including higher education.

The measurement of service quality in higher education is another important contribution of this study. If someone wants to improve service quality, first he/she has to measure it. By quantitatively evaluating service quality, managers may achieve several benefits, including:

- Identifying those aspects of service where they are performing better or worse.

- Identify the areas which need improvements, as well as areas where they are overperforming.

- Establish clear objective for employees and organization's units.

- Monitor the performance of units or individual employees. 
- Better understand customer expectations on service quality, what they want and how much they want.

- Benchmarking their service quality levels with competitor's levels.

- Setting overall sector standards on service quality.

- Measuring overall performance of company.

- By combining SERVQUAL scores with demographic data, organizations can effectively segment their consumer base.

This study also has several limitations. Firstly, only public universities were included in this study, while private institutions constitute a good part of higher education sector. Other studies might be more comprehensive in their evaluation of service quality in higher education. Secondly, the sample was drawn only from five universities in Albania, while the number of public universities is much greater. A more representative sample would have increased the validity of the results of the study. Finally, this study has to be replicated by other researchers in order to ascertain that the modified SERVQUAL scale used in higher education services holds its validity.

\section{References}

1. Andaleeb S., 1998. Determinants of customer satisfaction with hospitals: a managerial model, International Journal of Health Care Quality Assurance, Vol. 11, No. 6, pp. 181-7

2. Angur M., Nataraajan R., Jahera J. Jr., 1999. Service quality in the banking industry: an assessment in a developing economy, International Journal of Bank Marketing, Vol. 17, No. 3, pp. 116-23.

3. Avkiran N., 1999. Quality customer service demands human contact, The International Journal of Bank Marketing, Vol. 17, No. 2, pp. 35-68.

4. Babakus E., Mangold G., 1992. Adapting the SERVQUAL scale to hospital services: an empirical investigation, Health Service Research, Vol. 26, No. 6, pp. 767-80.

5. Bentler P. M., Bonett D. G., 1980. Significant tests and goodness of fit in the analysis of covariance structure, Psychological Bulletin, No. 88, pp. 588-606.

6. Bouman M., Van der Wiele T., 1992. Measuring service quality in the car service industry: building and testing an instrument, International Journal of Service Industry Management, Vol. 3, No. 4, pp. 4-16

7. Brysland A., Curry A., 2001. Service improvements in public services using SERVQUAL, Managing Service Quality, Vol. 11, No. 6, pp. 389-401

8. Carman J., 1990. Consumer perceptions of service quality: an assessment of the SERVQUAL dimension, Journal of Retailing, Vol. 66, No. 1, pp. 33-55.

9. Çerri S., 2012. Exploring factors affecting trust and relationship quality in a supply chain context, Journal of Business Studies Quarterly, Vol. 4, No. 1, pp. 74 - 90

10. Chang T.Z., Chen S.J., 1998. Market orientation, service quality and business profitability: a conceptual model and empirical evidence, Journal of Services Marketing, Vol. 12, No. 4, pp. 246-64

11. Comrey A. L., 1973. A first course in factor analysis, New York, NY, Academic Press

12. Cronin J. J., Taylor S. A., 1992. Measuring service quality: A reexamination and extension, Journal of Marketing, Vol. 56, No. 3, pp. 55-68.

13. Crosby P. B., 1982. The management of quality, Research Technology Management, Vol. 15, No. 4, pp. 10-12

14. Davis D., 1996. Business research for decision making, Belmont, CA, Duxbury Press 
15. Donnelly M., Kerr N. J., Rimmer R., Shiu E. M., 2006. Assessing the quality of police services using SERVQUAL, Policing: An International Journal of Police Strategies \& Management, Vol. 29, No. 1, pp. 92 - 105

16. Finn D., Lamb C., 1991. An evaluation of the SERVQUAL scale in a retailing setting, Advances in Consumer Research, Vol. 18, No. 4, pp. 83-90

17. Fornell C., Larcker D.F., 1981. Evaluating structural equation models with unobservable variables and measurement error, Journal of Marketing Research, Vol. 18, pp. 39-50

18. Frost F., Kumar M., 2001. Service quality between internal customers and internal suppliers in an international airline, International Journal of Quality \& Reliability Management, Vol. 18, No. 4, pp. 371-86

19. Gammie A., 1992. Stop at nothing in the search for quality, Human Resources, Vol. 5, Spring, pp. 35-8

20. Gefen D., Straub W.D., Boudreau M.C., 2000. Structural equation modeling and regression: I for research practice, Communications of the Association for Information Systems, Vol. 4, No. 7, pp. 1-80

21. Gronroos C., 2000. Service Management and Marketing - A customer relationship management approach, Wiley.

22. Grönroos C., 1984. A service quality model and its marketing implications, European Journal of Marketing, Vol. 18, No. 4, pp. 36 - 44

23. Gummesson E., 1998. Productivity, quality and relationship marketing in service operations, International Journal of Contemporary Hospitality Management, Vol. 10, No. 1, pp. $4-15$

24. Guru C., 2003. Tailoring e- service quality through CRM, Managing Service Quality, Vol. 13, No. 6, pp. 20-531

25. Hair J. F., Black W. C., Babin B.J., Anderson R. E., 2009. Multivariate data analysis, $7^{\text {th }}$ edition, Prentice Hall.

26. Hallowell R., 1996. The relationships of customer satisfaction, customer loyalty and profitability: an empirical study, International Journal of Service Industry Management, Vol. 7, No. 4, pp. 27-42

27. Hoxley M., 2000. Measuring UK construction professional service quality: the what, how, when and who, International Journal of Quality \& Reliability Management, Vol. 17, No. 4, pp. 511-26

28. Janda S., Trocchia P. J., Gwinner K. P., 2002. Consumer perceptions of Internet retail service quality, International Journal of Service Industry Management, Vol. 13, No. 5, pp. 412- 431

29. Juran J. M., 1988. Juran's quality control handbook, $4^{\text {th }}$ ed., New York- McGraw-Hill

30. Kwan P., Ng P., 1999. Quality indicators in higher education - comparing Hong Kong and China's students, Managerial Auditing Journal, Vol. 14, No. 1, pp. 20-77

31. Lai F., Hutchinson J., Li D, Bai C., 2007. An empirical assessment and application of SERVQUAL in mainland China's mobile communications industry, International Journal of Quality \& Reliability Management, Vol. 24, No. 3, pp. 244 - 262

32. Lassar W., Manolis C., Winsor R., 2000. Service quality perspectives and satisfaction in private banking, Journal of Services Marketing, Vol. 14, No. 3, pp. 244-71 
33. Lehtinen U., Lehtinen J. R., 1982. Service Quality: A Study of Quality Dimensions, Service Management Institute, Helsinki

34. Leonard F. S., Sasser W. E., 1982. The Incline of Quality, Harvard Business Review (September-October), pp. 163-171

35. McElwee G., Redman T., 1993. Upward appraisal in practice: an illustrative example using the QUALED model, Education and Training, Vol. 35, No. 2, pp. 27-31

36. Mehta S., Lalwani A., Han S., 2000. Service quality in retailing: relative efficiency of alternative measurement scales for different product-service environments, International Journal of Retail \& Distribution Management, Vol. 28, No. 2, pp. 62-72

37. Newman K., 2001. Interrogating SERVQUAL: a critical assessment of service quality measurement in a high street retail bank, The International Journal of Bank Marketing, Vol. 19, No. 3, pp. 126-39

38. Oldfield B., Baron S., 2000. Student perceptions of service quality in a UK university business and management faculty, Quality Assurance in Education, Vol. 8, No. 2, pp. 85-95

39. Parasuraman A., Berry L. L., Zeithaml V.A., 1988. SERVQUAL: A Multiple-Item Scale for Measuring Consumer Perceptions of Service Quality, Journal of Retailing, Vol. 64, No. 1, pp. $12-40$

40. Parasuraman A., Berry L.L., Zeithaml V.A., 1991. Refinement and reassessment of the SERVQUAL scale, Journal of Retailing, Vol. 67, No. 4, pp. 420-50

41. Parasuraman A., Zeithaml V.A., Berry L.L., 1985. A conceptual model of service quality and its implications for future research, Journal of Marketing, Vol. 49, No. 3, pp. 41-50

42. Philip G., Hazlett S., 2001. Evaluating the service quality of information services using a new ' $P$-C-P' attributes model, International Journal of Quality \& Reliability Management, Vol. 18, No. 9, pp. 900-16

43. Reichheld E.E., Sasser W. E., 1990. Zero defections: Quality comes to services, Harvard Business Review, Vol. 68 (September/October), 105-111

44. Remenyi D.S.J., Money A.H., 1994. Service quality and correspondence analysis in determining problems with the effective use of computer services, European Journal of Information Systems, Vol. 3, No. 1, pp. 2-13

45. Rigotti S., Pitt L., 1992. SERVQUAL as a measuring instrument for service provider gaps in business school, Management Research News, Vol. 15, No. 3, pp. 9-18

46. Rust R.T., Zahorik A.J., Keiningham T.L., 1995. Return on quality (ROQ): Making service quality financially accountable, Journal of Marketing, Vol. 59, No. 2, pp. 58-70

47. Shekarchizadeh A., Rasli A., Hon-Tat H., 2011. SERVQUAL in Malaysian universities: perspectives of international students, Business Process Management Journal, Vol. 17, No. 1 pp. $67-81$

48. Silvestro R., Cross S., 2000. Applying service profit chain in a retail environment, International Journal of Service Industry Management, Vol. 11, No. 3, pp. 244-68

49. Stevens J. P., 2002. Applied multivariate statistics for the social sciences, Mahwah, NJ, Lawrence Erlbaum Associates

50. Stewart K., Felicetti L., 1991. Marketing a public university to international students, Journal of Professional Service Marketing, Vol. 7, No. 1, pp. 67-74 
51. Sultan F., Merlin C., 2000. International service variants: airline passenger expectations and perceptions of service quality, Journal of Services Marketing, Vol. 14, No. 3, pp. 188216

52. Sureshchander G.S., Rajendran C., Anatharaman R.N., 2002. The relationship between service quality and customer satisfaction: a factor specific approach, Journal of Services Marketing, Vol. 16, No. 4, pp. 363-79

53. Tomovick C., Jones S., Al-Khatip J., Baradwaj B.G., 1996. An assessment of the service quality provided to foreign students at U.S. business school, Journal of Education for Business, No. 70, pp. 130-137

54. Van der Wal R., Pampallis A., Bond C., 2002. Service quality in a cellular telecommunications company: a South African experience, Managing Service Quality, Vol. 12 , No. 5, pp. 323-35

55. Widaman K.E., 1993. Common factor analysis versus principal components analysis: Differential bias in representing model parameters?, Multivariate Behavioral Research, No. 28, pp. 263-311

56. Wisniewski M., 2001. Using SERVQUAL to assess customer satisfaction with public sector services, Managing Service Quality, Vol.11, No.6, pp. 380-388

57. Wong J., 2002. Service quality measurement in a medical imaging department, International Journal of Health Care Quality Assurance, Vol. 15, No. 5, pp. 206-12 